\title{
Electrochemical $\mathrm{H}_{2} \mathrm{O}_{2}$ biosensor based on horseradish peroxidase encapsulated protein nanoparticles with reduced graphene oxide-modified gold electrode
}

\author{
Jeong-Hyeop Shin ${ }^{\dagger}$, Myeong-Jun Lee ${ }^{\dagger}$, Jin-Ha Choi, Ji-ae Song, Tae-Hwan Kim and Byung-Keun Oh ${ }^{*}$ (i)
}

\begin{abstract}
In this study, an electrochemical biosensor composed of a horseradish peroxidase (HRP)-encapsulated protein nanoparticles (HEPNP) was fabricated for the sensitive and selective detection of $\mathrm{H}_{2} \mathrm{O}_{2}$. The HEPNP has a three-dimensional structure that can contain a large amount of HRP; therefore, HEPNP can amplify the electrochemical signals necessary for the detection of $\mathrm{H}_{2} \mathrm{O}_{2}$. Furthermore, reduced graphene oxide $(\mathrm{rGO})$ was used to increase the efficiency of electron transfer from the HEPNP to an electrode, which could enhance the electrochemical signal. This biosensor showed a sensitive electrochemical performance for detection of $\mathrm{H}_{2} \mathrm{O}_{2}$ with signals in the range from 0.01-100 $\mu \mathrm{M}$, and it could detect low concentrations up to $0.01 \mu \mathrm{M}$. Furthermore, this biosensor was operated against interferences from glucose, ascorbic acid, and uric acid. In addition, this fabricated $\mathrm{H}_{2} \mathrm{O}_{2}$ biosensor showed selective detection performance in human blood serum. Therefore, the proposed biosensor could promote the sensitive and selective detection of $\mathrm{H}_{2} \mathrm{O}_{2}$ in clinical applications.
\end{abstract}

Keywords: Hydrogen peroxide, Horseradish peroxidase, Electrochemical, Reduced graphene oxide

\section{Introduction}

Hydrogen peroxide $\left(\mathrm{H}_{2} \mathrm{O}_{2}\right)$ is a very important in the fields of chemistry, biology, food studies, and in applications in clinical studies [1-3]. As a side product of some classic biochemical reactions catalyzed by enzymes, such as glucose oxidase, alcohol oxidase, lactate oxidase, and urate oxidase, $\mathrm{H}_{2} \mathrm{O}_{2}$ has been used to sense and track biochemical materials [4]. In the clinical and biological fields, $\mathrm{H}_{2} \mathrm{O}_{2}$ plays an important role in cellular mechanisms [5]. $\mathrm{H}_{2} \mathrm{O}_{2}$ is involved in reactive oxygen species (ROS) intracellular signaling as a mediator of several physiological processes, such as cell differentiation, proliferation, and cellular metabolism [6]. The high concentration of ROS,

\footnotetext{
*Correspondence: bkoh@sogang.ac.kr

'Jeong-Hyeop Shin and Myeong-Jun Lee contributed equally to this work Department of Chemical \& Biomolecular Engineering, Sogang University, Mapo-Gu, Seoul 04107, South Korea
}

which is associated with oxidative stress, can directly damage mitochondrial DNA [7], cellular proteins [8], and lipids [9]. For these reasons, $\mathrm{H}_{2} \mathrm{O}_{2}$ has been an attractive target of research in the field of biosensors. However, its concentration is usually low in biofluids. For instance, the steady-state concentration of $\mathrm{H}_{2} \mathrm{O}_{2}$ in mitochondria was reported in the few-nano-molar $(\sim \mathrm{nM})$ scale [10]. Some approaches used to sense $\mathrm{H}_{2} \mathrm{O}_{2}$ have included fluorimetry [11], spectrometry [12], chemiluminescence [13], and electrochemistry [14]. Among these techniques, electrochemical sensing methods, which are based on the direct electron transfer between the enzyme and the electrode, are widely used because of their simple, rapid, and high specificity [15-17]. However, an electrochemical sensor using only enzymes, such as horseradish peroxidase (HRP), had low sensitivity and could only detect $0.3 \mathrm{mM}$ of $\mathrm{H}_{2} \mathrm{O}_{2}$ [18]. 
To improve sensitivity, some researchers have used graphene oxide (GO) or reduced GO (rGO) because of its good properties, such as a large theoretical surface area, an extraordinary electrical character, good conductivity, durability, and many surface functional groups (hydroxyl, carboxyl, etc.) [19-21]. Because of these characteristics, the $\mathrm{H}_{2} \mathrm{O}_{2}$ electrochemical sensor could increase sensitivity; for example, HRP-palladium/GO could detect $25 \mu \mathrm{M}$ [22], $\mathrm{HRP} / \mathrm{GO} /$ silver could detect $25 \mu \mathrm{M}$ [23], and HRP/ $\mathrm{GO} /$ Chitosan/gold $(\mathrm{Au})$ could detect $5 \mu \mathrm{M}$ [24] in the linear range. However, its sensitivity was limited due to the low enzyme stability and two-dimensional enzyme immobilization, which could decrease the amount of enzymes fixed to the electrode. To overcome these disadvantages, recently, enzymatic nanoparticles have received attention because of their good properties in the field of enzymatic electrochemical detection. For instance, enzymatic nanoparticles can improve the stability of confined enzymes by protecting enzymes from denaturation, which can be carried out by external environmental conditions during analysis or storage [25]. Enzymatic nanoparticles can also increase catalytic activity by enlarging the surface reaction area and immobilizing a large amount of enzymes to the electrode with a threedimensional structure [26, 27]. Due to these advantages, many research studies have used three-dimensional nanoparticles to improve sensitivity and increase the stability of enzyme-based electrochemical detections of $\mathrm{H}_{2} \mathrm{O}_{2}$. For example, the heme-iron(III) group-immobilized carbon sphere $/ \mathrm{SiO}_{2} / \mathrm{Au}$ nanoparticle could detect $5 \mu \mathrm{M}$ of $\mathrm{H}_{2} \mathrm{O}_{2}$ [28], the Chitosan/HRP/poly-L-DOPA nanoparticle could detect $1 \mu \mathrm{M}$ of $\mathrm{H}_{2} \mathrm{O}_{2}$ [29], and the metalorganic framework/HRP cage and HRP onto mesoporous silica nanoparticle could detect $0.5 \mu \mathrm{M}$ of $\mathrm{H}_{2} \mathrm{O}_{2}$ in a linear range [30, 31]. However, there were still limits in detecting a very low concentration of $\mathrm{H}_{2} \mathrm{O}_{2}$, so nanoparticles that cause a strong enzyme reaction were needed to increase sensitivity.

In this study, our group developed three-dimensional HRP-encapsulated protein nanoparticles (HEPNP), which could encapsulate very large quantities of enzymes. The nanoparticle, which was created by albumin protein and HRP, could hold a huge quantity of HRP in a three-dimensional structure, which can cause a powerful enzyme chemical reaction. By using these particles, a large amount of HRP could be attached to the Au electrode surface with a three-dimensional structure. In addition, the Au electrode was treated with rGO before fixing the particles to increase the surface area of the electrode for increasing the number of immobilized particles and improving electrode's electrical property. In this paper, the synthesis of HEPNP was confirmed via transmission electron microscopy (TEM) and dynamic light scattering
(DLS). Fabricated HEPNP/rGO/Au working electrodes were confirmed by field emission scanning electron microscope (FE-SEM) and cyclic voltammetry (CV). To investigate the electrochemical sensing performance of the fabricated biosensor used to detect $\mathrm{H}_{2} \mathrm{O}_{2}, \mathrm{CV}$ and amperometric $\mathrm{i}-\mathrm{t}$ measurements were conducted.

\section{Methods/experimental}

\subsection{Materials}

Bovine serum albumin (BSA), glutaraldehyde, cysteamine, $0.01 \mathrm{M}$ phosphate buffered saline (PBS, pH 7.4), $100 \mathrm{mM}$ Tris buffer (pH7.4), 3,3',5,5'-Tetramethylbenzidine (TMB), L-ascorbic acid (AA), uric acid (UA), human serum, N-methyl-2-pyrrolidone (NMP), and rGO were purchased from Sigma Aldrich (USA). A bare Au electrode composed of gold $(50 \mathrm{~nm}) / \mathrm{Cr}(2 \mathrm{~nm}) / \mathrm{SiO}_{2}$ was prepared by the National Nanofab Center (Korea), and $30 \% \mathrm{H}_{2} \mathrm{O}_{2}, 95 \%$ sulfuric acid $\left(\mathrm{H}_{2} \mathrm{SO}_{4}\right)$ and pure ethanol $(\mathrm{EtOH})$ were purchased from Daejung Chemical (Korea). HRP was purchased from Thermo Fisher Scientific (USA), and $\mathrm{D}(+)$-glucose (dextrose anhydrous) was purchased from JUNSEI (Japan). Distilled water (DW) was purified through a Milli-Q system (USA).

\subsection{Synthesis of HEPNP}

HEPNP was synthesized via previous method by using the ethanol desolvation process. First, $100 \mu \mathrm{L}$ of $50 \mathrm{mg} /$ $\mathrm{mL}$ BSA solution in DW was mixed to $20 \mu \mathrm{L}$ of $25 \mathrm{mg} /$ $\mathrm{mL}$ HRP solution in DW. Added to the solution was $400 \mu \mathrm{L}$ of pure $\mathrm{EtOH}$ with a flow rate of $1 \mathrm{~mL} / \mathrm{min}$ while being stirred at $850 \mathrm{rpm}$ at $25{ }^{\circ} \mathrm{C}$. The mixture's color then turned opaque. For the crosslinking between BSA and HRP, $10 \mu \mathrm{L}$ of $4 \%$ glutaraldehyde was added, and the solution was incubated for $12 \mathrm{~h}$. After the reaction finished, a washing step was done by centrifugation (9000 rpm, $15 \mathrm{~min}$ ), and the supernatant was removed. The protein pellet was dispersed by $500 \mu \mathrm{L}$ of the washing solution $(0.01 \%$ Tween 20 in $0.01 \mathrm{M}$ PBS solution) three times. After the final centrifugation, the protein pellet was dispersed by $100 \mu \mathrm{L}$ of $1 \%$ BSA in Tris-buffer to deactivate glutaraldehyde. The HEPNP was stored at $4{ }^{\circ} \mathrm{C}$ in a dark room. Its characteristics were analyzed by using transmission electron microscopy (TEM) (JEOL1010, Japan) and dynamic light scattering (DLS) (Zeta Sizer, USA) analysis.

\subsection{Preparation of $\mathrm{HEPNP} / \mathrm{rGO} / \mathrm{Au}$ working electrode for sensing the $\mathrm{H}_{2} \mathrm{O}_{2}$}

The fabrication method of the HEPNP/rGO/Au electrode-based sensor for the detection of $\mathrm{H}_{2} \mathrm{O}_{2}$ was carried out as follows: Prior to any surface modification, the $\mathrm{Au}$ electrode $(5 \times 15 \mathrm{~mm})$ was cleaned using a piranha solution $\left(\mathrm{H}_{2} \mathrm{SO}_{4}: \mathrm{H}_{2} \mathrm{O}_{2}=7: 3\right)$ and rinsed with DW and $\mathrm{EtOH}$. 
On the surface of the cleaned $\mathrm{Au}$ electrode, cysteamine $(7.7 \mathrm{mg} / \mathrm{mL}$ in EtOH) acting as a chemical linker was immobilized. After cleaning the unreacted cysteamine, rGO $(100 \mu \mathrm{g} / \mathrm{mL}$ dissolved in NMP, $50 \mu \mathrm{L})$ was modified on the surface of the Au electrode by an electrostatic bond between the rGO's carboxylic functional group and the cysteamine's amine functional group and then incubated at $75{ }^{\circ} \mathrm{C}$. After $12 \mathrm{~h}$, the rGO-immobilized $\mathrm{Au}$ electrode $(\mathrm{rGO} / \mathrm{Au})$ was washed with $\mathrm{DW}$ and dried completely. Finally, $40 \mu \mathrm{L}$ of HEPNP was dropped on the $\mathrm{rGO} / \mathrm{Au}$ electrode and incubated for $12 \mathrm{~h}$ at $25^{\circ} \mathrm{C}$. The final product $\mathrm{HEPNP} / \mathrm{rGO} / \mathrm{Au}$ electrode was washed using a washing solution and kept in a refrigerator at $4{ }^{\circ} \mathrm{C}$ until used. A schematic diagram of the completed $\mathrm{HEPNP} / \mathrm{rGO} / \mathrm{Au}$ working electrode's $\mathrm{H}_{2} \mathrm{O}_{2}$ biosensing progress is shown in Fig. $1 . \mathrm{H}_{2} \mathrm{O}_{2}$ was reduced by HRP

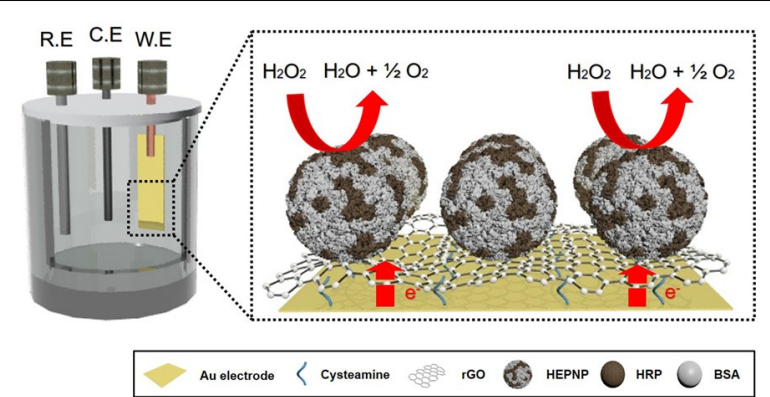

Fig. 1 Schematic diagram of $\mathrm{H}_{2} \mathrm{O}_{2}$ electrochemical sensing principle of the biosensor using Horseradish peroxidase-encapsulated protein nanoparticles (HEPNP) and reduced graphene oxide $(\mathrm{rGO})$ modified Au electrode. R.E reference electrode, C.E counter electrode, and W.E working electrode) in the HEPNP, which was located on the surface of the working electrode, and the electron transfer from the $\mathrm{Au}$ electrode to the $\mathrm{H}_{2} \mathrm{O}_{2}$ through the rGO and HEPNP. This electron transfer was analyzed via the electrochemical detection technique, such as $\mathrm{CV}$ and amperometry i-t curve. All electrochemical tests were performed using the CHI-660e electrochemical workstation (USA) with a three-electrode system, which consisted of the working electrode, the platinum counter electrode, and a silver/silver chloride $(\mathrm{Ag} / \mathrm{AgCl})$ double-junction reference electrode.

\section{Results and discussion}

\subsection{Characterization of the synthesized HEPNP}

As shown in Fig. 2a a TEM image shows the spherical morphology of an HEPNP with a diameter of about $100 \mathrm{~nm}$ at $\mathrm{pH}$ 8. The particle size of this HEPNP could be controlled by adjusting the $\mathrm{pH}$ value of the mixed solution, and this was due to the different molecular interactions between the proteins. This phenomenon arose from the charge of the amino acid residues, which changes depending on the $\mathrm{pH}$. The spherical HEPNP indicated that HEPNP had a three-dimensional structure; therefore, the HEPNP had a larger surface area, which could hold a greater amount of HRP compared to an HRP single layer.

In our previous study, it was investigated the signal amplification of HEPNP in comparison to HRP via the enzyme-substrate reaction with a TMB substrate. The absorbance value of the same amount of HRP molecule and HEPNP, which were synthesized at $\mathrm{pH} 8$, was measured. The results indicated that the HEPNP exhibited an amplified signal ca. 40 times larger than that of the HRP a

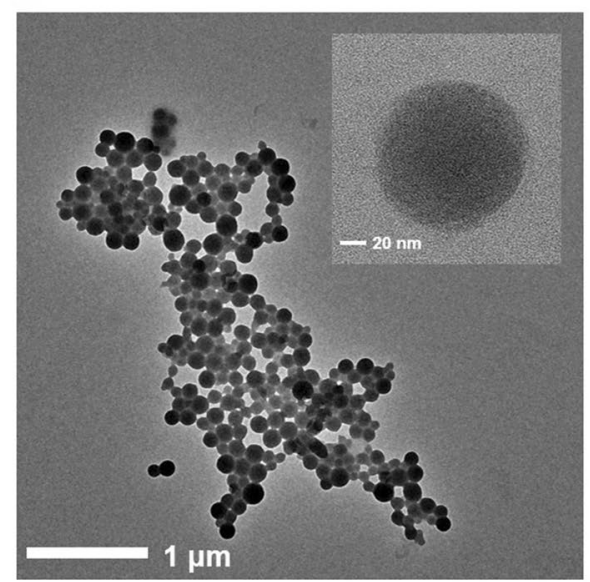

b

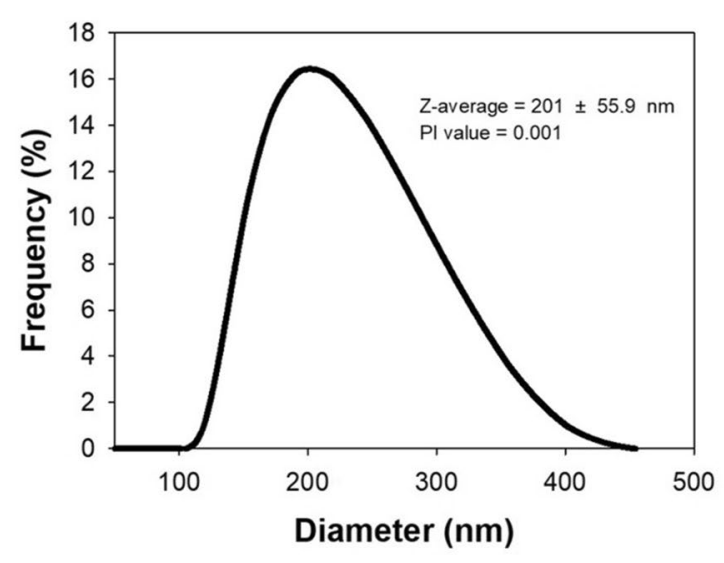

Fig. 2 Characteristics of HEPNP. a Transmission electron microscopy (TEM) image of the synthesized HEPNP at pH 8, b Dynamic light scattering (DLS) analysis of the synthesized HEPNP at pH 8 
molecules. The significant increase in the signal of the HEPNP indicate their good applicability for the improvement of biosensor's sensitivity [32].

To measure the particle size of HEPNP, DLS analysis was employed. As shown in Fig. 2b, the DLS results indicate that the sizes of HEPNP were distributed in the range of about $100-400 \mathrm{~nm}$, the value of the Z-average was $150-250 \mathrm{~nm}$, and the PI value was 0.001 . The results revealed slightly different particle sizes from the results of TEM. Because DLS measures the hydrodynamic radius of the dispersed particles associated with ionic and solvent layers whereas TEM provides information about the particles' core sizes, this cannot evaluate the particles' hydrodynamic radius. Hence, the size obtained by DLS is usually bigger than that by TEM. In this study, to measure DLS, the HEPNP was dissolved in PBS buffer solution. Therefore, the HEPNP was swollen in the colloidal state. However, the HEPNP immobilized on the carboncoated copper grid was in a completely dried state under vacuum conditions when using TEM.

\subsection{Surface characterization of modified electrodes}

Figure $3 \mathrm{a}-\mathrm{c}$ shows the surface morphologic properties of the working electrode, which were respectively composed of a bare $\mathrm{Au}$ electrode, rGO-modified $\mathrm{Au}$ electrode $(\mathrm{rGO} / \mathrm{Au})$, and HEPNP/rGO-modified $\mathrm{Au}$ electrode $(\mathrm{HEPNP} / \mathrm{rGO} / \mathrm{Au})$, that were investigated by FE-SEM. The rGO sheets were successfully modified on the $\mathrm{Au}$ electrode as shown in Fig. 3b. Furthermore, it showed the morphology of the rGOs, which was formed in sheets about $3 \mu \mathrm{m}$ in length. As shown in Fig. 3c, the HEPNP particles were tightly covered over the rGO sheets. Because the rich functional groups on the rGO surfaces enable protein molecules to efficiently adsorb onto the rGO surface, and rGO interacts with protein molecules through hydrophobic interaction, electrostatic forces, hydrogen bonding, and $\pi-\pi$ stacking interactions occurred due to the typical $\mathrm{sp}^{2}$ carbon structure [33].

To compare the enzymatic activation of modified electrodes, an enzyme-substrate reaction was performed via colorimetric assay with a TMB substrate. Bare Au, HRPimmobilized $\mathrm{Au}(\mathrm{HRP} / \mathrm{Au})$, and HEPNP-immobilized $\mathrm{Au}(\mathrm{HEPNP} / \mathrm{Au})$ were prepared respectively, and their colorimetric signals were compared with the enzymatic reaction of the TMB substrate on each electrode surface. In the case of the HEPNP/Au electrode, it indicated a higher intensity at an absorbance $450 \mathrm{~nm}$ compared to the HRP/Au electrode because the HEPNP has a threedimensional structure, which could hold a greater quantity of enzymes than am HRP single layer. Therefore, the HEPNP/Au electrode showed a powerful enzymatic reaction when using the TMB substrate (data not shown).

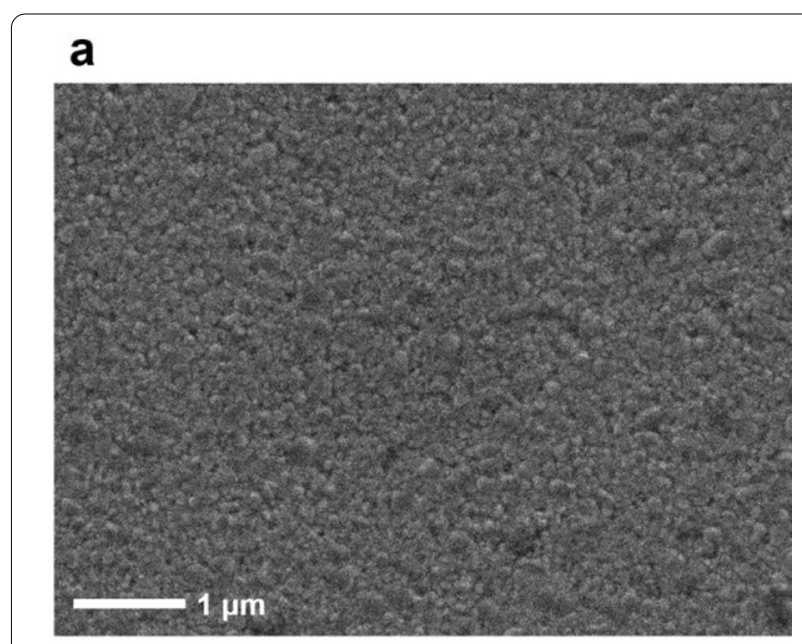

b

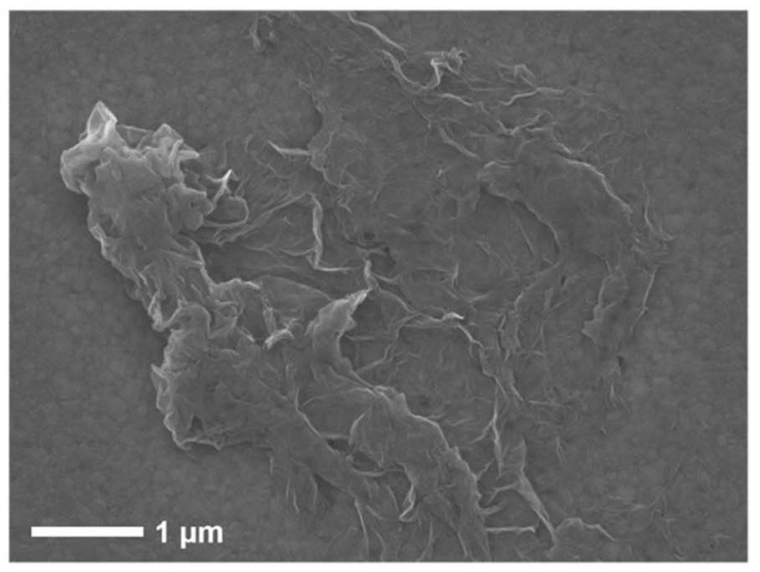

C

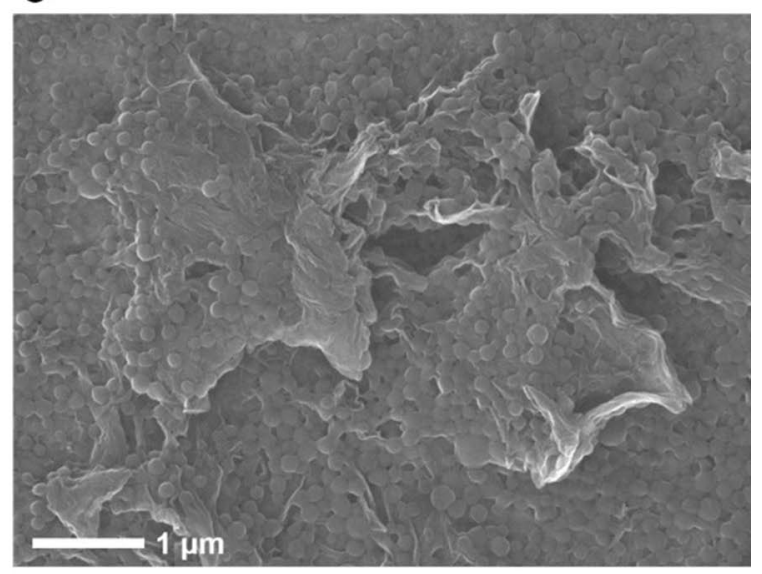

Fig. 3 FE-SEM images of: a Bare Au electrode, b rGO/Au electrode, and $\mathbf{c} H E P N P / r G O / A u$ electrode

\subsection{Electrochemical properties of $\mathrm{HEPNP} / \mathrm{rGO} / \mathrm{Au}$ biosensor for sensitive detection of $\mathrm{H}_{2} \mathrm{O}_{2}$}

HRP is heme-protein that can catalyze the reductive reaction of $\mathrm{H}_{2} \mathrm{O}_{2}$. The mechanism of electrocatalytic 
reduction of $\mathrm{H}_{2} \mathrm{O}_{2}$ is demonstrated in the following:

$$
\begin{aligned}
& \operatorname{HRP}\left(\mathrm{Fe}^{\mathrm{III}}\right)+\mathrm{H}_{2} \mathrm{O}_{2} \\
& \rightarrow \text { Compound } \mathrm{I}\left(\mathrm{Fe}^{\mathrm{IV}}=\mathrm{O}, \mathrm{P}^{\bullet+}\right)+\mathrm{H}_{2} \mathrm{O} \\
& \text { Compound } \mathrm{I}\left(\mathrm{Fe}^{\mathrm{IV}}=\mathrm{O}, \mathrm{P}^{\bullet+}\right) \\
& +\mathrm{H}_{2} \mathrm{O}_{2} \rightarrow \operatorname{HRP}\left(\mathrm{Fe}^{\mathrm{III}}\right)+\mathrm{O}_{2} \\
& \operatorname{HRP}\left(\mathrm{Fe}^{\mathrm{III}}\right)+\mathrm{e}^{-} \rightarrow \operatorname{HRP}\left(\mathrm{Fe}^{\mathrm{II}}\right) \text { at electrode } \\
& \operatorname{HRP}\left(\mathrm{Fe}^{\mathrm{II}}\right)+\mathrm{O}_{2} \rightarrow \operatorname{HRP}\left(\mathrm{Fe}^{\mathrm{II}}-\mathrm{O}_{2}\right) \text { fast } \\
& \operatorname{HRP}\left(\mathrm{Fe}^{\mathrm{II}}-\mathrm{O}_{2}\right)+2 \mathrm{e}^{-}+2 \mathrm{H}^{+} \\
& \rightarrow \mathrm{HRP}\left(\mathrm{Fe}^{\mathrm{II}}\right)+\mathrm{H}_{2} \mathrm{O}_{2} \text { at electrode }
\end{aligned}
$$

$\mathrm{H}_{2} \mathrm{O}_{2}$ acts as an oxidant and a reductant in Eqs. (1) and (2), respectively, in which, $\mathrm{HRP}\left(\mathrm{Fe}^{\mathrm{III}}\right)$ is oxidized by $\mathrm{H}_{2} \mathrm{O}_{2}$ to produce an intermediate of compound $\mathrm{I}\left(\mathrm{Fe}^{\mathrm{IV}}=\mathrm{O}, \mathrm{P}^{\cdot+}\right)$ first. Then, compound $\mathrm{I}$ is reduced by $\mathrm{H}_{2} \mathrm{O}_{2}$ through a two-electron transfer pathway and produces the native $\operatorname{HRP}\left(\mathrm{Fe}^{\mathrm{III}}\right)$ again and $\mathrm{O}_{2}$. After $\operatorname{HRP}\left(\mathrm{Fe}^{\mathrm{III}}\right)$ accepts one electron from the electrode to form HRP $\left(\mathrm{Fe}^{\mathrm{II}}\right)$ shown as Eq. (3), $\mathrm{HRP}\left(\mathrm{Fe}^{\mathrm{II}}\right)$ reacts with $\mathrm{O}_{2}$ in a solution very rapidly to form HRP $\left(\mathrm{Fe}^{\mathrm{II}}-\mathrm{O}_{2}\right)$, which then undergoes electrochemical reduction at the electrode at the same potential as that of HRP ( $\mathrm{Fe}^{\mathrm{III}}$ ) reduction, producing $\mathrm{H}_{2} \mathrm{O}_{2}$ and HRP-Fe $\left({ }^{\mathrm{II}}\right)$ again and forming a catalytic cycle with Eq. (4). $\mathrm{H}_{2} \mathrm{O}_{2}$ produced in Eq. (5) will participate in Eqs. (1) or (2) to produce $\mathrm{O}_{2}$, which will then induce or promote the catalytic cycle of Eqs. (4) and (5) [34]. Therefore, an electrochemical signal was caused by the electrocatalysis of immobilized HRP to reduce $\mathrm{H}_{2} \mathrm{O}_{2}$.

The electrochemical properties of the HEPNP/rGO/Au biosensor were investigated via $\mathrm{CV}$ as shown in Fig. $4 \mathrm{a}-\mathrm{c}$. The parameters for $\mathrm{CV}$ were in the voltage range of 0 to $-0.8 \mathrm{~V}$, a $60 \mathrm{mV} / \mathrm{s}$ scan rate, a $1 \mathrm{mV} / \mathrm{s}$ sampling interval, $2 \mathrm{~s}$ of quiet time, and at a $1 \times 10^{-5}(\mathrm{~A} / \mathrm{V})$ sensitivity. To confirm the electrochemical signal enhancement of the fabricated HEPNP biosensor in the detection of $\mathrm{H}_{2} \mathrm{O}_{2}$, the different modified electrodes were prepared respectively in the presence of $100 \mu \mathrm{M} \mathrm{H}_{2} \mathrm{O}_{2}$ in $0.01 \mathrm{M}$ PBS solution. As shown in Fig. 4a, because of the rGO's electrical properties, which include a good conductivity and the induction of the enhancement of electron transfer, the fabricated $\mathrm{HRP} / \mathrm{rGO} / \mathrm{Au}$ and $\mathrm{HEPNP} / \mathrm{rGO} / \mathrm{Au}$ electrode showed an increased reduction current response at $-0.45 \mathrm{~V}$ in comparison to the bare $\mathrm{Au}$ electrode. In

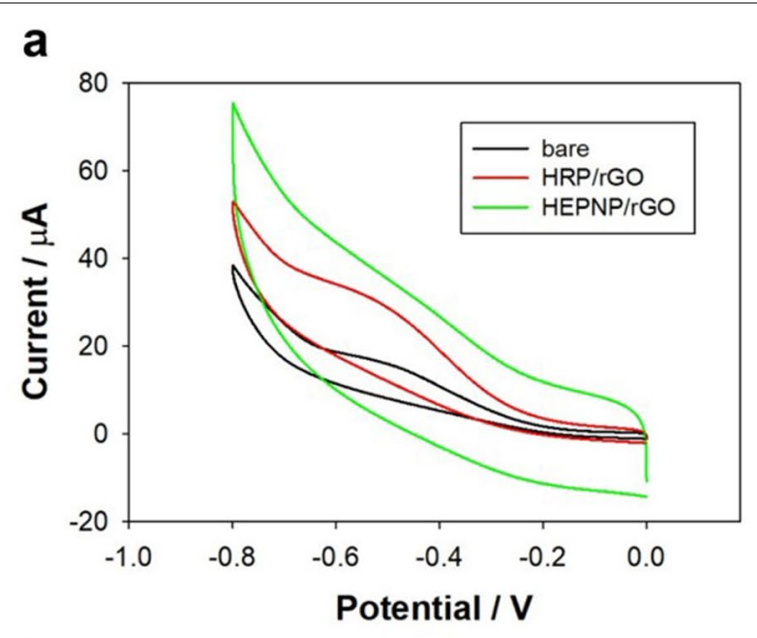

b

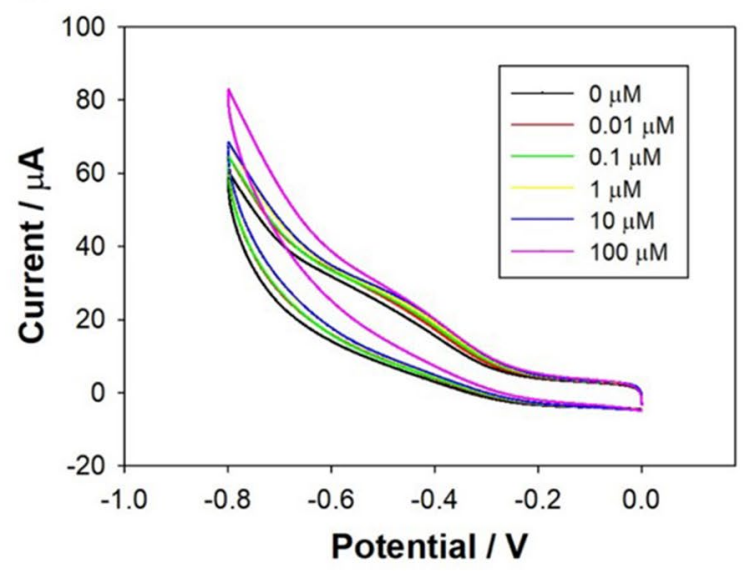

C

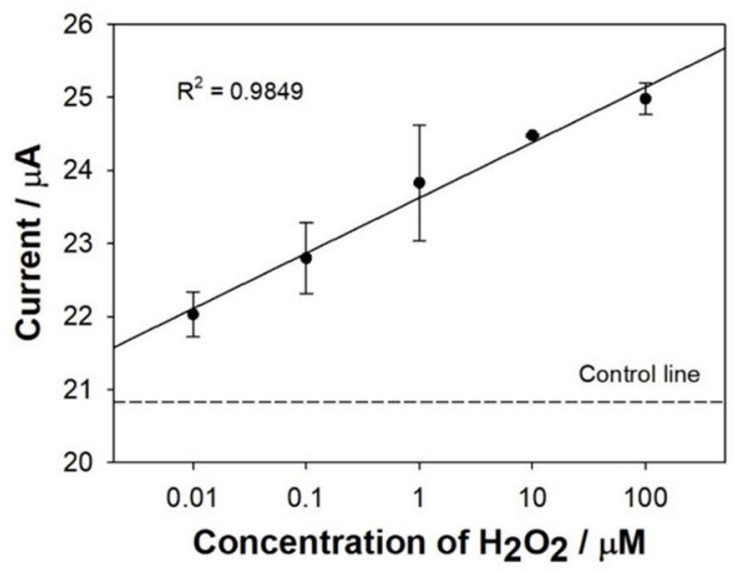

Fig. 4 Cyclic voltammetric responses of: a Bare Au electrode, HRP/ $\mathrm{rGO} / \mathrm{Au}$ electrode, and $\mathrm{HEPNP} / \mathrm{rGO} / \mathrm{Au}$ electrode in the presence of $100 \mu \mathrm{M} \mathrm{H}_{2} \mathrm{O}_{2}$, b HEPNP/rGO/Au electrode as a function of $\mathrm{H}_{2} \mathrm{O}_{2}$ concentration, and $\mathbf{c}$ Linear plot of the reduction current peak at the HEPNP/rGO/Au electrode as a function of $\mathrm{H}_{2} \mathrm{O}_{2}$ concentration $(n=3)$ 
comparison to the modified electrodes, the $\mathrm{CV}$ current responses of the $\mathrm{HEPNP} / \mathrm{rGO} / \mathrm{Au}$ electrode $(31 \mu \mathrm{A}$ at $-0.45 \mathrm{~V})$ were higher than that of $\mathrm{HRP} / \mathrm{rGO} / \mathrm{Au}(24 \mu \mathrm{A}$ at $-0.45 \mathrm{~V}$ ), indicating that the HEPNP had enhanced the electrochemical signals in the reduction of $\mathrm{H}_{2} \mathrm{O}_{2}$ compared to HRP. Because the HEPNP had a greater amount of HRP, which catalyzed the reduction of $\mathrm{H}_{2} \mathrm{O}_{2}$, the HEPNP caused a strong enzymatic reaction with $\mathrm{H}_{2} \mathrm{O}_{2}$, so the electrochemical signal was enhanced. To confirm the reduction current in various scan rates, the $\mathrm{CV}$ of the HEPNP/rGO/Au was acquired by increasing the scan rates from 20 to $200 \mathrm{mV} / \mathrm{s}$. Obviously, the reduction currents were enhanced with the increase of the scan rates (data not shown). To investigate the electrochemical sensitivity performance of the HEPNP biosensor in the detection of $\mathrm{H}_{2} \mathrm{O}_{2}$, various concentrations from 0.01$100 \mu \mathrm{M} \mathrm{H} \mathrm{H}_{2} \mathrm{O}_{2}$ were prepared. As shown in Fig. $4 \mathrm{~b}$, the reduction currents were enhanced with increases in the $\mathrm{H}_{2} \mathrm{O}_{2}$ concentrations. According to the CV's responses, the detection limit of the HEPNP biosensor for $\mathrm{H}_{2} \mathrm{O}_{2}$ was $0.01 \mu \mathrm{M}$. It showed a low detection limit for $\mathrm{H}_{2} \mathrm{O}_{2}$ compared to other HRP-based biosensors in Table 1. The calibration curve against the various concentration of $\mathrm{H}_{2} \mathrm{O}_{2}$ at $-0.45 \mathrm{~V}$ was plotted in Fig. 4c with a correlation coefficient of 0.9849 . These results indicate that the fabricated $\mathrm{HEPNP} / \mathrm{rGO} / \mathrm{Au}$ biosensor had good sensitivity and could detect low concentration up to $0.01 \mu \mathrm{M}$ of $\mathrm{H}_{2} \mathrm{O}_{2}$.

\subsection{Selective amperometry response of the HEPNP/rGO/ Au electrode in the detection of $\mathrm{H}_{2} \mathrm{O}_{2}$}

To test the selectivity performance of the HEPNP/rGO/ $\mathrm{Au}$ electrode to $\mathrm{H}_{2} \mathrm{O}_{2}$, some co-existing species in biofluids, such as glucose, UA, and AA, were analyzed via the amperometry response with $\mathrm{H}_{2} \mathrm{O}_{2}$. Parameters for $\mathrm{i}-\mathrm{t}$ curve amperometry analysis were a $0.1 \mathrm{~s}$ sampling interval, $0 \mathrm{~s}$ quiet time, $1 \times 10^{-5}(\mathrm{~A} / \mathrm{V})$ sensitivity, and $-0.45 \mathrm{~V}$ as the initial voltage. All samples were prepared at a final concentration of $100 \mu \mathrm{M}$ on PBS. Figure 5a shows that a

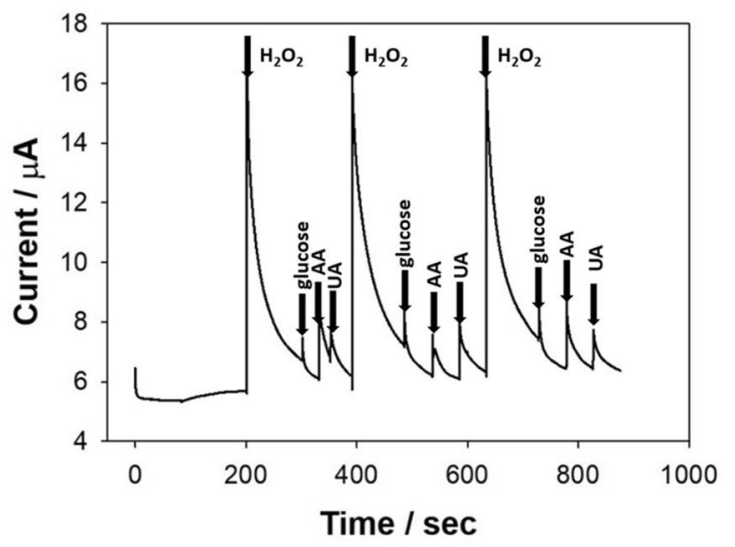

b

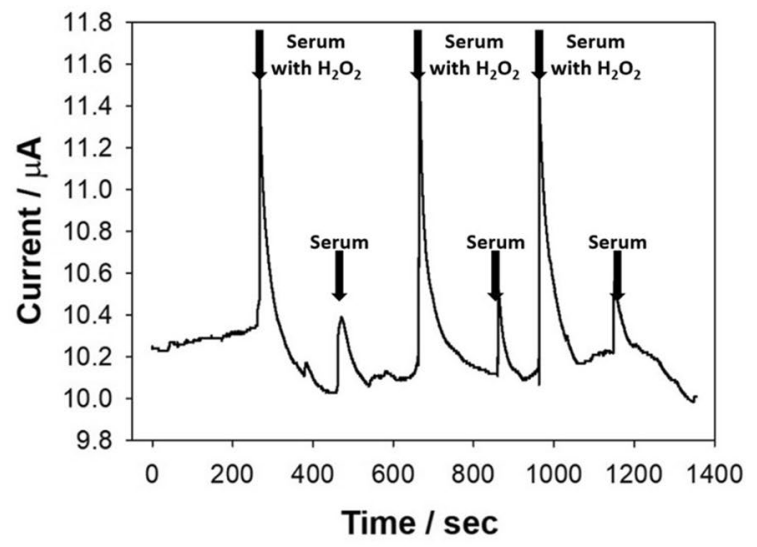

Fig. 5 Amperometric responses of the HEPNP/rGO/Au electrode for: $\mathbf{a} \mathrm{H}_{2} \mathrm{O}_{2}$, glucose, ascorbic acid, and uric acid at the same concentration $(100 \mu \mathrm{M})$ in PBS buffer and $\mathbf{b} \mathrm{H}_{2} \mathrm{O}_{2}(10 \mu \mathrm{M})$ in human serum

the response current was increased to be much higher in the case of $\mathrm{H}_{2} \mathrm{O}_{2}$ addition than the results of glucose, $\mathrm{AA}$, and UA addition. It can be seen that this fabricated

Table 1 Comparison of the electrochemical performance of HRP-based biosensors

\begin{tabular}{|c|c|c|c|c|}
\hline Modified electrode & Potential (V) & Linear range $(\mu \mathrm{M})$ & Detection limit $(\mu \mathrm{M})$ & Reference \\
\hline $\mathrm{HRP} / \mathrm{TB} / \mathrm{CCB}$ & -0.25 & $0.429-455$ & 0.17 & [35] \\
\hline HRP-MIL100(Cr)-B & -0.3 & $0.5-3000$ & 0.1 & [36] \\
\hline HRP-BMIM-BF ${ }_{4} / \mathrm{SWCNTS/CFUME}$ & -0.35 & $0.49-10.2$ & 0.13 & {$[37]$} \\
\hline Flower-like $\mathrm{Bi}_{2} \mathrm{WO}_{6}$ & -0.35 & $0.5-100$ & 0.18 & {$[38]$} \\
\hline $\mathrm{HRP}-\mathrm{MoS}_{2}-\mathrm{Gr}$ & -0.08 & $0.2-1.103$ & 0.049 & [39] \\
\hline $\mathrm{CO}_{3} \mathrm{O}_{4} / \mathrm{MWCNTs} /$ gelatin/HRP & -0.3 & $0.74-19$ & 0.74 & [40] \\
\hline HEPNP/rGO/Au electrode & -0.45 & $0.01-100$ & 0.01 & Present work \\
\hline
\end{tabular}

TB toluidine blue, CCB ceramic composite biosensor, MIL100(Cr)-B mil100(cr)-b boronic acid functionalized metal-organic frameworks, BMIM 1-butyl-3methylimidazolium tetrafluoroborate, SWCNTs Single-walled carbon nanotubes, CFUME Carbon fiber ultramicroelectrodes, MoS ${ }_{2}$ molybdenum disulfide gr graphene, $\mathrm{CO}_{3} \mathrm{O}_{4}$ cobalt oxide, MWCNTs multiwall carbon nanotubes, HEPNP horseradish peroxidase encapsulated protein nanoparticles, $r G O$ reduced graphene oxide Au: gold electrode 
biosensor showed highly selective performance in the amperometric response of $\mathrm{H}_{2} \mathrm{O}_{2}$ towards glucose, $\mathrm{UA}$, and AA.

To verify the sensing performance of $\mathrm{H}_{2} \mathrm{O}_{2}$ by the $\mathrm{HEPNP} / \mathrm{rGO} / \mathrm{Au}$ electrode sensor in the actual serum sample, an experiment was conducted with a human blood serum sample. After $200 \mathrm{~s}$ of signal stabilization, $20 \mu \mathrm{L}$ of serum with $10 \mu \mathrm{M} \mathrm{H}_{2} \mathrm{O}_{2}$ was added to $5 \mathrm{~mL}$ of $0.01 \mathrm{M}$ PBS solution, and $20 \mu \mathrm{L}$ of serum without $\mathrm{H}_{2} \mathrm{O}_{2}$ was added to $5 \mathrm{~mL}$ of $0.01 \mathrm{M}$ PBS solution three times. Figure $5 \mathrm{~b}$ shows the high response current when using serum with $\mathrm{H}_{2} \mathrm{O}$ but a weak response current when using serum without $\mathrm{H}_{2} \mathrm{O}_{2}$. In addition, it can also be confirmed that $\mathrm{H}_{2} \mathrm{O}_{2}$ in the serum can be measured using a constant signal. These results demonstrate that the HEPNP/rGO/Au-based electrochemical biosensor can selectively detect $\mathrm{H}_{2} \mathrm{O}_{2}$ in human serum with stable response and can be applied to clinical sample analysis.

\section{Conclusion}

In this study, an electrochemical biosensor composed of HEPNP was fabricated for highly sensitive and selective $\mathrm{H}_{2} \mathrm{O}_{2}$ detection. In this biosensor, $\mathrm{rGO}$ was used to increase efficiency of electron transfer from Au electrode to HEPNP, and HEPNP was used for increasing sensitivity by fixing a great amount of HRP with a three-dimensional structure on the surface of electrode. The results of the electrochemical investigation suggest that the $\mathrm{HEPNP} / \mathrm{rGO} / \mathrm{Au}$ biosensor results in a highly enhanced electrochemical signal compared to using an $\mathrm{HRP} / \mathrm{rGO} /$ $\mathrm{Au}$. This biosensor could operate linearly with different concentrations of $\mathrm{H}_{2} \mathrm{O}_{2}$ and could detect low concentrations up to $0.01 \mu \mathrm{M}$. Furthermore, this biosensor had a good selectivity for the detection of $\mathrm{H}_{2} \mathrm{O}_{2}$ and could detect $\mathrm{H}_{2} \mathrm{O}_{2}$ dissolved in human serum. Consequently, this proposed $\mathrm{HEPNP} / \mathrm{rGO} / \mathrm{Au}$ biosensor has a wide range of possible applications in the measurement of very small quantities of $\mathrm{H}_{2} \mathrm{O}_{2}$ in the chemical, biological, and clinical fields.

\section{Abbreviations \\ $\mathrm{H}_{2} \mathrm{O}_{2}$ : Hydrogen peroxide; HRP: Horseradish peroxidase; BSA: Bovine serum albumin; HEPNP: HRP encapsulated protein nanoparticles; Au: Gold electrode; rGO: Reduced graphene oxide; CV: Cyclic voltammetry; ROS: Reactive oxygen species; TEM: Transmission electron microscopy; DLS: Dynamic light scattering; FE-SEM: Field emission scanning electron microscope; PBS: Phosphate bufferd saline; TMB: 3,3',5,5'-Tetramethylbenzidine; AA: L-ascorbic acid; UA: Uric acid; NMP: N-methyl-2-pyrrolidone; DW: Distilled water.}

\footnotetext{
Acknowledgements

This research was supported by the National Research Foundation of Korea (NRF) grant funded by the Ministry of Science, ICT \& Future Planning (No. 2019R1F1A1061120), Korea Environment Industry\&Technology Institute (KEITI) through the program for the management of aquatic ecosystem health, funded by Korea Ministry of Environment(MOE). (No. 2020003030001), and "Human Resources Program in Energy Technology" of the Korea Institute
}

of Energy Technology Evaluation and Planning (KETEP), granted financial resource from the Ministry of Trade, Industry \& Energy, Republic of Korea. (No. 20174010201150)

\section{Authors' contributions}

$J-H S$ and M-JL contributed equally to this work. J-HS, M-JL, J-HC, and B-KO designed and wrote the manuscript. J-HS, M-JL, J-AS, and T-HK in performing the experiment. All authors read and approved the final manuscript.

\section{Funding}

It is already included in Acknowledgements.

\section{Availability of data and materials}

The datasets used and/or analyzed during the current study are available from the corresponding author on reasonable request.

\section{Competing interests}

The authors declare that they have no competing interests.

Received: 20 July 2020 Accepted: 6 December 2020

Published online: 16 December 2020

References

1. S.C. Chang, J. Food Hyg. Saf. 32(6), 447-454 (2017)

2. B. Halliwell, M.V. Clement, L.H. Long, FEBS Lett. 486(1), 10-13 (2000)

3. A.K. Yagati, J.W. Choi, Electroanalysis 26(6), 1259-1276 (2014)

4. W. Chen, S. Cai, Q.Q. Ren, W. Wen, Y.D. Zhao, Analyst 137(1), 49-58 (2012)

5. R.F. Eich, T.S. Li, D.D. Lemon, D.H. Doherty, S.R. Curry, J.F. Aitken, A.J. Mathews, K.A. Johnson, R.D. Smith, G.N. Phillips, J.S. Olson, Biochemistry 35(22), 6976-6983 (1996)

6. N.D. Marzo, E. Chisci, R. Giovannoni, Cells 7(10), 156 (2018)

7. K. Ishikawa, K. Takenaga, M. Akimoto, N. Koshikawa, A. Yamaguchi, H. Imanishi, K. Nakada, Y. Honma, J. Hayashi, Science 320(5876), 661-664 (2008)

8. M.M. Gaschler, B.R. Stockwell, Biochem. Biophys Res. Commun. 482(3), 419-425 (2017)

9. I. Dalle-Donne, D. Giustarini, R. Colombo, R. Rossi, A. Milzani, Trends Mol Med. 9(4), 169-176 (2003)

10. E. Cadenas, K.J.A. Davies, Free Radic Biol Med. 29(3-4), 222-230 (2000)

11. F. Molaabasi, S. Hosseinkhani, A.A. Moosavi-Movahedi, M. Shamsipur, Rsc Adv. 5(42), 33123-33135 (2015)

12. H.M. Cocheme, C. Quin, S.J. McQuaker, F. Cabreiro, A. Logan, T.A. Prime, I. Abakumova, J.V. Patel, I.M. Fearnley, A.M. James, C.M. Porteous, R.A.J. Smith, S. Saeed, J.E. Carre, M. Singer, D. Gems, R.C. Hartley, L. Partridge, M.P. Murphy, Cell Metab. 13(3), 340-350 (2011)

13. Y. Jia, S. Sun, X. Cui, X. Wang, L. Yang, Talanta 205, 120139-120144 (2019)

14. M. Shamsipur, A. Pashabadi, F. Molaabasi, RSC Adv. 5(76), 61725-61734 (2015)

15. E. Kurowska, A. Brzozka, M. Jarosz, G.D. Sulka, M. Jaskula, Electrochim. Acta. 104, 439-447 (2013)

16. J. Yoon, T. Lee, G.B. Bapurao, J. Jo, B.K. Oh, J.W. Choi, Biosens. Bioelectron. 93, 14-20 (2017)

17. L. Yang, C. Xu, W. Ye, W. Liu, Sens. Actuators B Chem. 215, 489-496 (2015)

18. Y.T. Kong, M. Boopathi, Y.B. Shim, Biosens Bioelectron. 19(3), 227-232 (2003)

19. A.K. Geim, K.S. Novoselov, Nat Mater. 6(3), 183-191 (2007)

20. K.S. Novoselov, Z. Jiang, Y. Zhang, S.V. Morozov, H.L. Stormer, U. Zeitler, J.C. Maan, G.S. Boebinger, P. Kim, A.K. Geim, Science 315(5817), 1379-1379 (2007)

21. C. Lee, X. Wei, J.W. Kysar, J. Hone, Science 321(5887), 385-388 (2008)

22. S. Nandini, S. Nalini, R. Manjunatha, S. Shanmugam, J.S. Melo, G.S. Suresh, J Electroanal Chem 689, 233-242 (2013)

23. S. Nalini, S. Nandini, S. Shanmugam, S.E. Neelagund, J.S. Melo, G.S. Suresh, J Solid State Electrochem. 18(3), 685-701 (2014)

24. K. Zhou, Y. Zhu, X. Yang, J. Luo, C. Li, S. Luan, Electrochim Acta. 55(9), 3055-3060 (2010)

25. Z. Zhou, M. Hartmann, Chem Soc Rev. 42(9), 3894-3912 (2013)

26. X. Cao, Y. Li, Z. Zhang, J. Yu, J. Qian, S. Liu, Analyst 137(24), 5785-5791 (2012) 
27. J. Yu, Y. Zhang, S. Liu, Biosens Bioelectron. 55, 307-312 (2014)

28. Y. Wang, X. Chen, J. Zhu, Electrochem Commun. 11(2), 323-326 (2009)

29. M. Dai, T. Huang, L. Chao, Q. Xie, Y. Tan, C. Chen, W. Meng, Talanta 149, 117-123 (2016)

30. W. Chen, W. Yang, Y. Lu, W. Zhu, X. Chen, Anal Methods. 9(21), 3213-3220 (2017)

31. G. Bai, X. Xu, Q. Dai, Q. Zheng, Y. Yao, S. Liu, C. Yao, Analyst 144(2), 481-487 (2019)

32. J.H. Choi, Y.T. Lim, B.K. Oh, Sci Adv Mater. 6(11), 2572-2576 (2014)

33. Y. Huang, A. Hara, C. Terashima, A. Fujishima, M. Takai, Carbon 152, 354-362 (2019)

34. H. Zhao, Q. Sheng, J. Zheng, Microchim Acta. 176, 177-184 (2012)

35. K. Thenmozhi, S.S. Narayanan, Mater Sci Eng C. 70, 223-230 (2017)
36. H. Dai, W. Lu, X. Zuo, Q. Zhu, C. Pan, X. Niu, J. Liu, H. Chen, X. Chen, Biosens Bioelectron. 95, 131-137 (2017)

37. Q.Q. Ren, J. Wu, W.C. Zhang, C. Wang, X. Qin, G.C. Liu, Z.X. Li, Y. Yu, Sens Actuators B Chem. 245, 615-621 (2017)

38. H. Liu, K. Guo, C. Duan, X. Chen, Z. Zhu, Mater Sci Eng C. 64, 243-248 (2016)

39. H. Song, Y. Ni, S. Kokot, Biosens Bioelectron. 56, 137-143 (2014)

40. C. Kacar, B. Dalkiran, P.E. Erden, E. Kilic, Appl Surf Sci. 311, 139-146 (2014)

\section{Publisher's Note}

Springer Nature remains neutral with regard to jurisdictional claims in published maps and institutional affiliations.

\section{Submit your manuscript to a SpringerOpen ${ }^{\odot}$ journal and benefit from:}

- Convenient online submission

- Rigorous peer review

- Open access: articles freely available online

- High visibility within the field

Retaining the copyright to your article

Submit your next manuscript at $\boldsymbol{\nabla}$ springeropen.com 